\title{
DIGITALIZATION OF THE TAX ACCOUNTING SYSTEM IN THE CONDITIONS OF INTEGRATION AND MODERNIZATION OF THE ECONOMY
}

\begin{abstract}
The article reviews the development of the tax accounting system in the conditions of integration, modernization and digitalization of the economy. The history of the formation of national accounting systems shows that at a certain stage of economic development, all States face with the distribution of the interests of the state and the owner, as well as the distribution of various financial, tax and management reports. The rational accounting requirement determines the feasibility of its organization as a unified accounting information system based on integration into the organization and effective relations of various types of accounting. In defining the communication interaction of financial and tax statements as a subsystem of the corporate accounting system, it should ensure the relative independence of the accounting process organization from a certain type of reporting.
\end{abstract}

Key words: three-component integrated system, fiscalization, transaction, digitalization, Unified register, specifications, functional requirement system requirements.

DOI: 10.51180/RPS.2020.15.2.005.

\section{Author}

\section{Yssupov Ulagat}

PhD, Assoc.Professor of the Department «Accounting and audit» Kazakh University of Economics,

Finance and International trade

(Nur-Sultan, Republic of Kazakhstan)

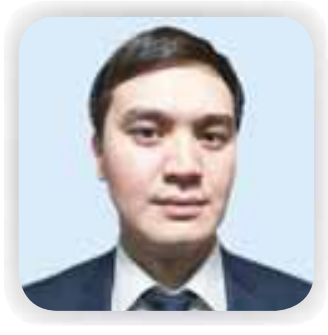

A rational accounting requirement determines the expediency of organizing it as a single accounting information system based on integration in the enterprise and effective interconnection of various accounting types. In determining the communication interaction of financial and tax statements as a subsystem of the enterprise accounting system the relative independence of the accounting process organization from specific reporting should be ensured.

An integrated accounting system addresses the needs of all interested users within a single accounting information base. At the same time, the costs of its creation, maintenance and implementation in the accounting process of enterprises must be economically justified.
The weak development of theoretical issues of interaction between accounting and tax accounting and the practical need for organizational and methodological approaches to their integration is based on the relevance of the chosen topic of the scientific article and the content of the issues under consideration.

Three-component integrated system - an integrated system consisting of a cash register with the function of recording and transmitting data, a device for accepting non-cash payments (POSterminal), as well as equipment fitted with trade management automation system, provision of services, performing works and accounting for goods, or a hardware and software complex that replaces all three components of the 
integrated system. Requirements for TIS and its accounting, the procedure for its installation and usage are established by the competent authority in consultation with the Central state body in the field of state planning, the competent authority implementing the state policy in the area of communications and the National Bank of the Republic of Kazakhstan. Maintenance and support of its Unified Register is carried out by the CGD of the Ministry of Finance of the Republic of Kazakhstan. Server hardware and workstations that provide the functioning of the integrated system are located on the territory of the Republic of Kazakhstan.

TIS provides the unified record of all the objects of entrepreneurial activity the integration of automation system of the Department of trade, provision of services, works and goods account with any number of other components of the TIS (cash machines with the function of fixing and transmission of data, included into the state register of cash registers, systems (devices) for accepting cash payments).

The TIS provides in the manner prescribed by Law of the Republic of Kazakhstan dated 28 February 2007 "On accounting and financial reporting" and International Financial Reporting Standard (IFRS) for small and medium businesses account for the movement of inventory (capitalization, debt, travel, sales, returns sales and purchase, inventory) in quantitative and value terms, on one or more warehouses on balances, reserves, and lots of goods for the purpose of completing each of the operations by forming the appropriate document and implementing sales, fiscalization (with the issuance of a fiscal receipt) and disposal of inventory within one operation (transaction) ;

- sales of goods, works and services in quantitative and value terms;

- cash flows from operating, investment and financial activities, including accounting for banking and cash operations, with all changes for the reporting period displayed;

- incomes';
- calculations on staff remuneration;

- settlements on tax obligations and social payments [1].

Thus, the TIS carries out the sale, fiscalization (with the issuance of a fiscal receipt) and disposal of inventory within a single operation (transaction).

In addition, TIS models that are allowed to be used on the territory of the Republic of Kazakhstan for tax purposes are subject to inclusion in the unified register of TIS, and publication on the website of the state revenue Committee. In this end, the owner of the TIS must apply an application, the required documents and the TIS for testing. In turn, the TIS user (an individual entrepreneur applying a special tax regime (STR) on the basis of a patent or on the basis of a simplified Declaration) is obliged to register the TIS with the state revenue authorities at the location of the TIS user and specify data on them in the tax reports.

If the requirements of the Tax code are not met the increased threshold for registration for value added tax and ceiling of income sole proprietor which apply the STR based on the simplified Declaration cannot be applied. Regarding the acceptance of payment by card in the territory of the Republic of Kazakhstan, cash payments are made with the mandatory use of cash registers. Cash payments are payments made for the purchase of goods, performance of works, provision of services by means of cash and (or) payments using payment cards. The goods accounting system means equipment fitted with an automation system for the management of trade, providing services, performing works, and accounting for goods [2].

Let us consider the stages of registration a three-component integrated system in the figure.

Consider the requirements for a threecomponent integrated system and its accounting in table 1.

To meet the technical requirements, the following principles must be observed, consider them in Figure 2. 


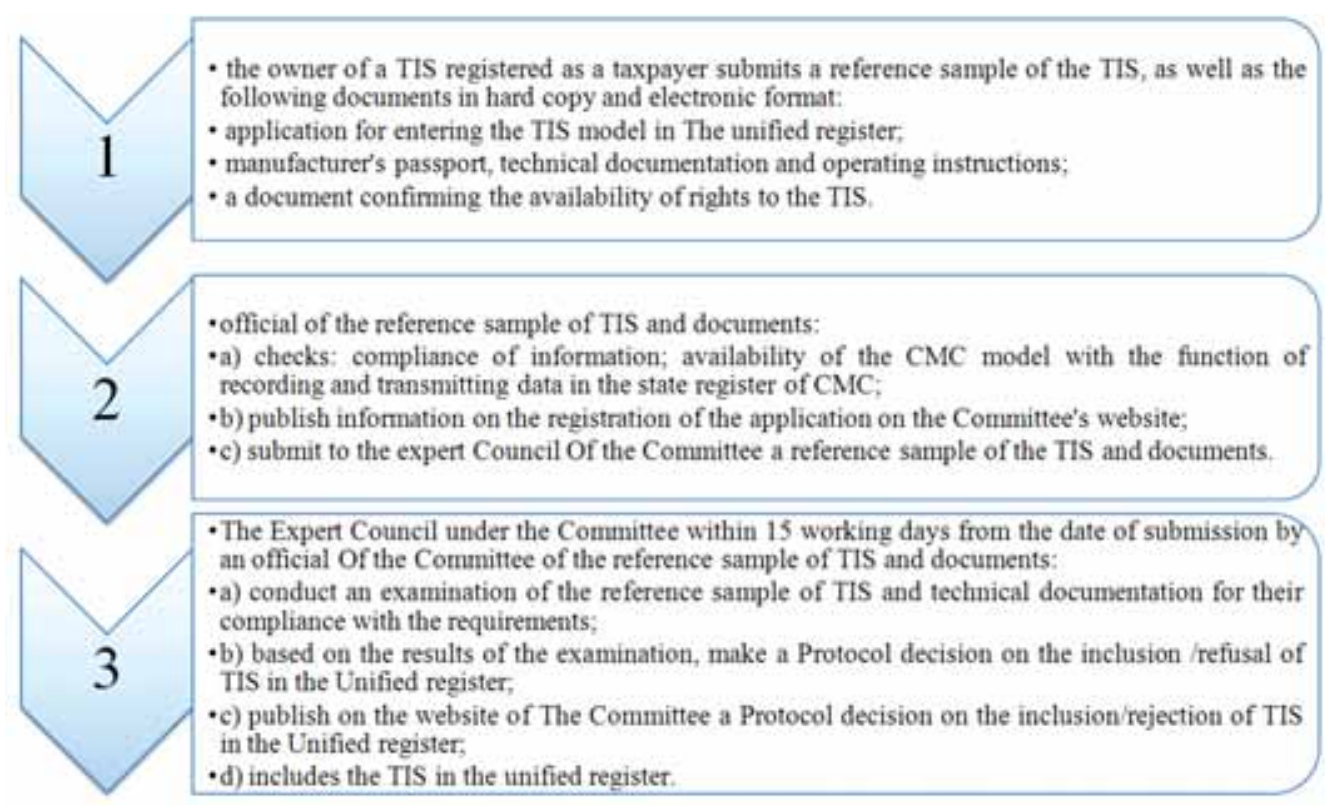

Figure 1. Stages of registration a three-component system integrated system Note - compiled according to the source [3].

\section{Table 1 - technical requirements for a three-component integrated system and its accounting}

\begin{tabular}{|c|c|}
\hline $\begin{array}{l}\text { Name of re- } \\
\text { quirements }\end{array}$ & A description of the requirements \\
\hline \multirow[t]{16}{*}{ Specifications } & - technical means for the operation of the TIS; \\
\hline & - system software; \\
\hline & - ensuring the operation of TIS in fiscal mode; \\
\hline & - ensuring acceptance of non-cash payments; \\
\hline & - ensuring acceptance of non-cash payments; \\
\hline & $\begin{array}{l}\text { - providing the possibility of automated reading of the marking of goods and } \\
\text { (or) services; }\end{array}$ \\
\hline & - the formation, acquisition and utilization of ESF; \\
\hline & $\begin{array}{l}\text { - enabling integration of the trade management automation system, service } \\
\text { delivery; }\end{array}$ \\
\hline & - compliance with system requirements; \\
\hline & - ensuring reliable storage of information; \\
\hline & - providing daily automatic backup of the database and system transaction log; \\
\hline & - ensuring control over the completeness of input data; \\
\hline & $\begin{array}{l}\text { - availability of reference lists of the product range, currencies, suppliers and } \\
\text { buyers of goods, employees, tax reference books; }\end{array}$ \\
\hline & - integration with warehouse and retail equipment and printer support; \\
\hline & - the user can select the language (state or Russian) used in the TIS operation; \\
\hline & $\begin{array}{l}\text { - compliance with information security requirements established by the leg- } \\
\text { islation of the Republic of Kazakhstan on Informatization. }\end{array}$ \\
\hline
\end{tabular}

Note - compiled according to the source [3] 


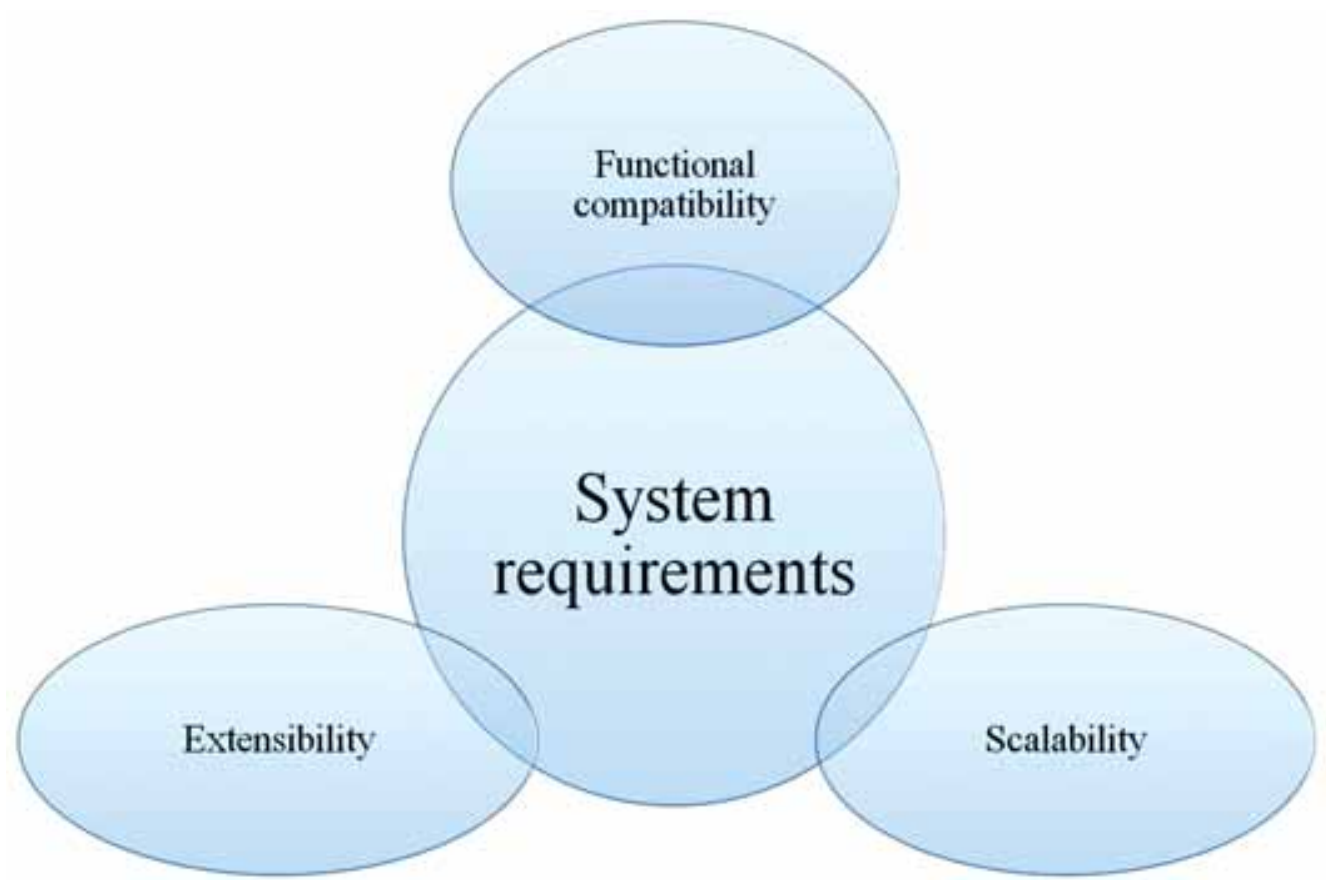

Figure 2. System requirements

Note - compiled according to the source [3]

Consider the functional requirements for a three-component integrated system and its accounting in table 2 .

Table 2 - functional requirements for a three-component integrated system and its accounting

\begin{tabular}{|c|c|}
\hline $\begin{array}{l}\text { Name of require- } \\
\text { ments }\end{array}$ & A description of the requirements \\
\hline 1 & 2 \\
\hline \multirow[t]{8}{*}{$\begin{array}{l}\text { Functional require- } \\
\text { ments }\end{array}$} & $\begin{array}{l}\text { - formation and use of primary accounting documents used for registra- } \\
\text { tion of operations or events }\end{array}$ \\
\hline & $\begin{array}{l}\text { - ensuring the accumulation and systematization of information con- } \\
\text { tained in primary documents accepted for accounting }\end{array}$ \\
\hline & - providing: \\
\hline & $\begin{array}{l}\text { a) movement of inventory (recording, write-off, transfer, sales, returns } \\
\text { of sales and purchases, inventory) in quantitative and monetary terms; }\end{array}$ \\
\hline & $\begin{array}{l}\text { b) sales of goods, works and services in quantitative and monetary } \\
\text { terms; }\end{array}$ \\
\hline & $\begin{array}{l}\text { c) cash flows from operating, investment and financial activities, includ- } \\
\text { ing accounting for banking and cash operations, with all changes for } \\
\text { the reporting period displayed; }\end{array}$ \\
\hline & d) income; \\
\hline & e) calculations on staff remuneration. \\
\hline
\end{tabular}

Note - compiled according to the source [3]. 
Digitalization of the economy brings its own rules to the system of collecting, storing and processing information of socio-economic processes. In this regard, accounting and tax accounting been called upon to new requirements. Its transformation will help keep it relevant in competition with new multi-functional digital information systems.

As part of the implementation of the President's address to the people of Kazakhstan "New development opportunities in the fourth industrial revolution" dated January 10, 2018, the Ministry of Finance is implementing a number of projects aimed at digitalizing tax and customs administration [4].

Today, the Internet-economy is growing at a the rate of up to twenty-five percent a year in developing countries, and any sector of the economy can't even draw near this rate. Ninety percent of all global data was created in just over the last three years. Already 35 billion devices are connected to the Internet and exchange data - this figure is five times higher than the total population of the world.

Efforts to digitalization lead to the creation of a new society where human capital is actively developing - business ef- ficiency and speed are increased through automation and other new technologies, and the dialogue of citizens with their States becomes simple and open. These changes are caused by the introduction of many technological innovations applied in different industries in recent years. The ways of production and obtaining added value are changing dramatically, and new requirements for people's education and labor skills are emerging.

Virtual warehouse - a new module of the ESF information system designed to control the movement of goods in automatic mode. This definition is given in the rules for issuing electronic invoices. The system is located on the portal esfvs.gov.kz.

Control over the sale of goods within the country is carried out in the information system "Electronic invoices". As of January 15, 2019, the number of registered participants in the system is 281 thousand. (Sole proprietors 108 thousand, legal entities - 173 thousand), which issued 163 million ESF. Of these, 86 thousand are VAT payers [5].

Based on the current information system "Electronic invoices", the "Virtual warehouse" module has been implement-
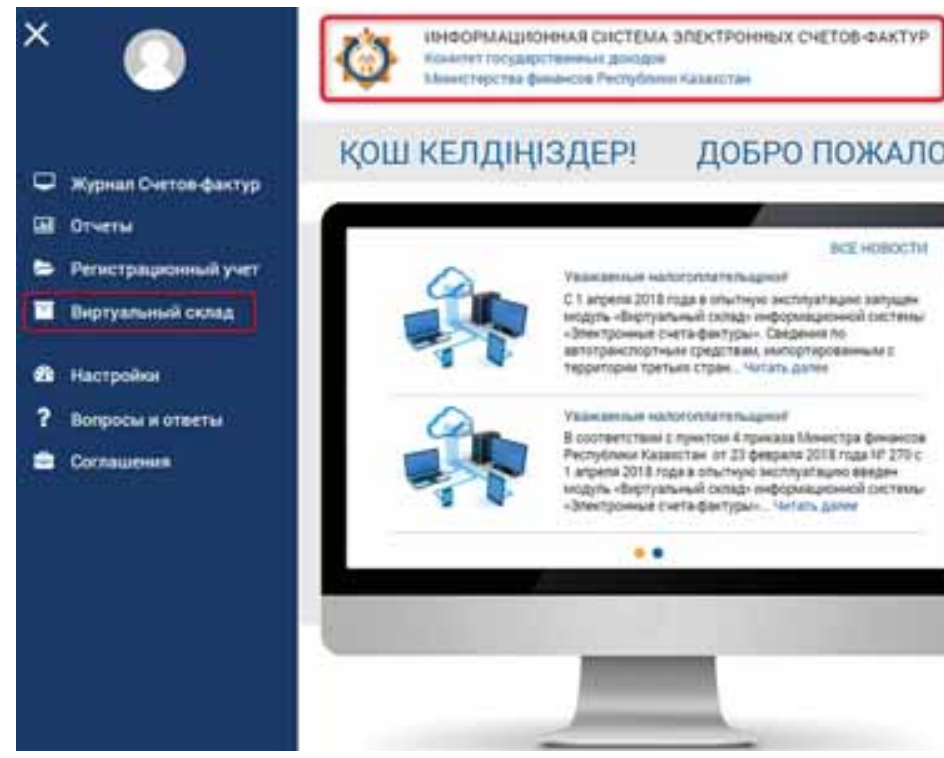

\section{ҚОШ КЕЛДІНІЗДЕР! ДОБРО ПОЖАЛОВАТЬ! WELCOMЕ!}

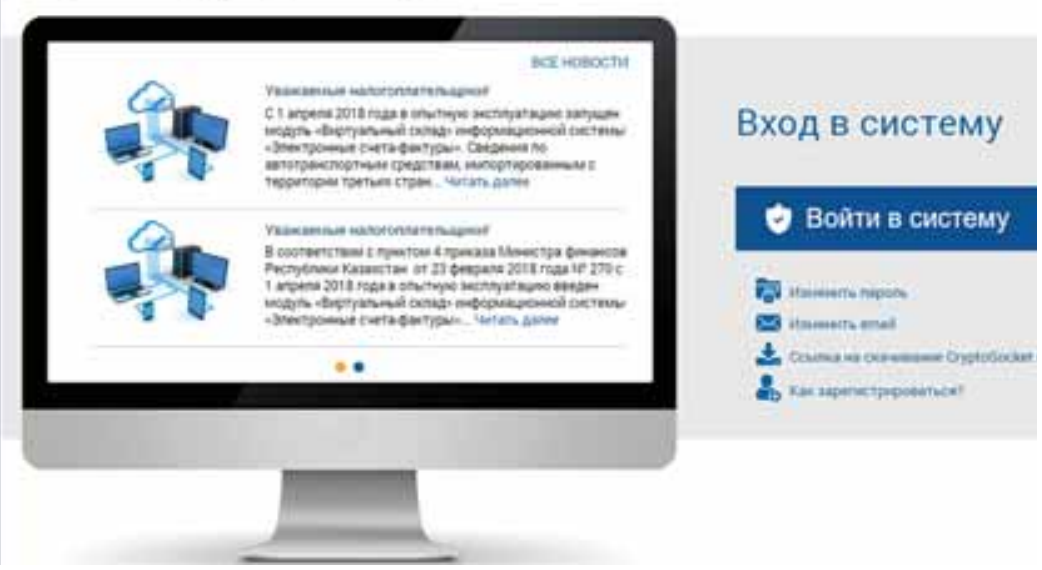

Figure 3. Electronic invoice information system 
ed, enabled in real time to automatically calculate the balance of goods in the taxpayer's warehouse, as well as track the chain of movement from import in Kazakhstan to final consumption (write-off).

Thus, the improvement of tax accounting practices is associated with the expansion of the information potential of the existing economic space and the digitalization of the economy. At the same time, information technologies cause significant modifications, both in the methodology and in the applied direction of the science of tax accounting. In this regard, the automation of tax accounting in accordance with new needs is a necessary stage in its development. Changes and improvements to this accounting method will help keep it relevant in the ега of universal digitalization.

\section{References}

1. Law of the Republic of Kazakhstan dated February 28, 2007 No. 234-III "On accounting and financial reporting" (with amendments and additions as of 01.01.2020). www.kgd.gov.kz (accessed: 01.07.2020).

2. Code of the Republic of Kazakhstan dated December 25, 2017 No. 120-VI "On taxes and other mandatory payments to the budget (Tax code)" (with amendments and additions as of 02.07.2020) // www.kgd.gov.kz (accessed: 03.07.2020).

3. Салық есебі: теория, әдістеме, ұйымдастыру: монография/ Ұ.Б.Юсупов; ред. М.Қ.Әлиев. - Астана: Мастер По ЖШС, 2016. - 1656.

4. Message of the President of the Republic of Kazakhstan N. Nazarbayev to the people of Kazakhstan dated October 5, 2018. "Growth of welfare of Kazakhstan citizens: increasing income and quality of life" // www.akorda.kz (accessed 25.12.2019).

5. Electronic resource: https://esf.gov.kz:8443/esf-web/login

\section{Translated from Russian into English by Podobueva Veronika, student of RUDN University}

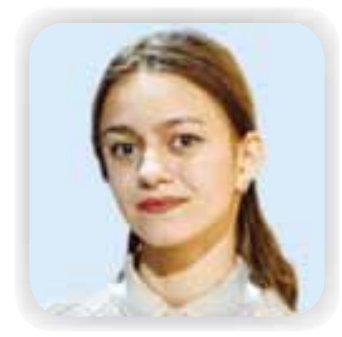

